Vol. 2, No. 2, December 2021

DOI: https:// doi.org/10.18196/ijiep.v2i2.12992

\title{
The Effectiveness of Istighfar Dzikr Therapy in Increasing Domestic Violence Victims' Resilience
}

\author{
Trya Dara Ruidahasi, Fuad Nashori* \\ Universitas Islam Indonesia, Indonesia \\ *Corresponding email: fuadnashori@uii.ac.id
}

\section{ARTICLE INFO}

Article History

Received : 26/10/2021

Revised : 25/11/2021

$17 / 12 / 2021$

$23 / 12 / 2021$

Accepted: 23/12/2021

\section{Keywords}

Dzikr, Istighfar, Therapy,

Domestic Violence,

Resilience, Islamic

Psychology

\begin{abstract}
Resilience encourages individuals to face, overcome, and become stronger in difficult situations, especially for wives of domestic violence victims to face their issues. This study aims to observe the effectiveness of istighfar $d z i k r$ therapy in increasing the resilience of the wives. This study used a mixed-method with sequential explanatory design. The first stage was a quantitative approach involving 12 wives as victims of domestic violence in Yogyakarta. The second stage was a qualitative approach to deepen the quantitative data. The participants were divided into the control group $(n=6)$ and the treatment group $(n=6)$. They were selected using a purposive sampling technique, and the data were collected by CD-RISC (Connor-Davidson Resilience Scale). This study applied a nonrandomized control group with a pre-test-post-test design. The data analysis technique quantitatively used the SPSS software version 25. Then, Anava Mixed Design was used to analyze. The results showed an increase in resilience scores in the treatment group, and the treatment group had higher resilience scores than the control group. Participants in the treatment group were able to maintain the therapeutic effect two weeks after the istighfar dzikr therapy.
\end{abstract}

This is an open-access article under the CC BY-SA license.

\section{Citation:}

Ruidahasi, T. D., \& Nashori, F. (2021). The effectiveness of istighfar dzikr therapy in increasing domestic violence victims' resilience. International Journal of Islamic Educational Psychology, 2(2), 142-165. DOI: https:// doi.org/10.18196/ijiep.v2i2.12992 
Ruidahasi \& Nashori | The Effectiveness of Istighfar Dzikr Therapy in Increasing Domestic Violence Victims' Resilience

\section{INTRODUCTION}

Marriage is an important part of the human life cycle. Marriage aims to realize happiness (sakinah) with love (mawaddah), affection (rahmah), and Allah's trust (Amanah). When love is lost, there is still mercy. If there is no mercy left, then there is trust. As long as the husband and wife are religious, their trust will be maintained (Erniati, 2015). However, the reality shows that many marriage trusts are broken. One concrete evidence is domestic violence. Domestic violence can be perpetrated by husbands against their wives (Erniati, 2015), wives against their husbands (Basri at al., 2018), and parents against children (Ikrawati et al., 2016). Some media even reported child violence against parents (Rosadi, 2018; liputan6.com, 2019). Based on this explanation, other evidence is that the most common domestic violence occurs when the wife becomes the victim of violence by her husband.

Violence against women is highly prevalent. Based on the World Health Organization's (WHO) report, violence in intimate relationships is the most common violence. Globally, 1 in 3 women worldwide has experienced physical violence and sexual violence in their lifetime. Most perpetrators of violence are spouses (World Health Organization, 2020). Reports from the United Kingdom, United States, China, and other countries showed an increase in domestic violence cases since the COVID-19 outbreak (World Health Organization, 2020). Violence in Indonesia is also widely reported. Based on data from the Online Information System for the Protection of Children and Women (SIMFONI PPA), violence cases until November 2020 reached 15,350 cases and continue to increase every day (Kementerian Pemberdayaan Perempuan dan Perlindungan Anak, 2020). Male victims reached $21 \%$ (3,250 cases), while female victims reached $79 \%$ $(12,100$ cases). Thus, the amount of violence against women is higher.

The Annual Records of the National Commission on Violence Against Women (Komisi Nasional Anti Kekerasan terhadap Perempuan next written "Komnas Perempuan") also reported that most cases of violence against women occur in the private sphere. Violence in the personal realm includes violence against wives (KTI), violence in courtship (KDP), violence against girls (KTAP), and other personal domains. The most prominent type of violence against women is domestic violence (KDRT) (Komnas Perempuan, 2020). The Annual Records of the National Commission on Violence Against Women (2020) showed that violence against women in the private sphere reached $75 \%(11,105$ cases). Violence in the household/private sphere is violence against wives (KTI), with 6,555 cases (59\%). These cases have happened in Indonesia (Komnas Perempuan, 2016; Komnas Perempuan, 2017; Komnas Perempuan, 2018; Komnas Perempuan, 2019; Komnas Perempuan, 2020).

Mustaqim (2020) explained that violence cases against women in the Special Region of Yogyakarta have also consistently been high in the last five years. One of the community institutions that also reports to Komnas Perempuan, the Rifka Annisa Woman Crisis Center Yogyakarta, focuses on violence against women. 
Ruidahasi \& Nashori | The Effectiveness of Istighfar Dzikr Therapy in Increasing Domestic Violence Victims' Resilience

Data from the agency noted that from 2014 to 2019, violence cases ranged from 250 to more than 300 each year. The latest data include 329 cases of violence against women in Yogyakarta. The first rank is violence against wives (KTI), totaling 184 cases in 2019. Rifka Annisa's page (2018) showed violence cases against women handled. From 2012 to 2017, violence against wives (KTI) always occupied the highest cases.

The causes that encourage domestic violence according to PP No. 9 of 1975 concerning Law No. 1 of 1974 on marriage, one of the foundations of the Religious Courts Agency, are disharmony, lack of responsibility, and economic factors. In addition, it is caused by third-party interference, moral crisis, unhealthy polygamy, forced marriage, underage marriage, and others (Komnas Perempuan, 2016). Socio-culturally, there are several causes of domestic violence, including (1) patriarchal culture that supports men as superior beings and women as inferior beings; (2) erroneous understanding of religious lessons, thus placing men as parties who may control women; (3) the imitation of a son against a father who likes to do violence to his mother; (4) the condition of families living in poverty; (5) the husband's bad habits, such as drunk, frustrated, or having a mental disorder (Muhajarah, 2017).

Kementerian Pemberdayaan Perempuan dan Perlindungan Anak or The Ministry of Women's Empowerment and Child Protection (2011) explains that violence against women is defined as all types of violence committed against women and can result in harm such as physical, sexual, or psychological suffering to adult women or girls and adolescents. The acts include threats, coercion, intentionally and arbitrarily depriving women of their freedom. Acts of violence in physical, sexual, and psychological can occur in the family or community environment. Reality has shown that in Indonesia, cases of domestic violence increase from year to year, with the largest percentage being violence against wives (Muhajarah, 2017).

Domestic violence can cause anxiety, fear, and lack of confidence for the victims. Several studies (Ramadani \& Yuliani, 2017; Maisah \& SS, 2016; Vinatalia et al., 2009) showed that domestic violence could have several impacts, including fear, anxiety, post-traumatic stress, withdrawal, and eating and sleeping disorders. Wives as victims of domestic violence by their husbands tend to lose selfconfidence and feel powerless to act (Sutrisminah, 2012). The interest in self-care also decreases, and the lifestyle is not regular. They tend to be quiet and lose the courage to think and act, feel confused and forgetful, and often hurt themselves and even try to commit suicide (Aditya, 2014). They will also become aggressive, temperamental and raise rough emotions in speaking and acting (Deborah et al., 2018). Various studies have proved that some violent cases develop into suicide as reported by the mass media (Muliawan, 2018; Enam, 2018; Nasution, 2019; Redaksi., 2020; Efendi, 2020; and JPNN.com, 2020).

Based on the explanation above, domestic violence is a difficult condition for the wife as a victim. To get through these difficult conditions, a wife as a victim of 
domestic violence needs the ability to survive, adapt and rise from difficult conditions, called resilience. Sari (2018) stated that the better the resilience of wives who experience domestic violence, the more they will rise and establish positive relationships, solve problems and find solutions, live independently without relying on others, and be aware of goals for the future. Dala's research (2019) found that a resilient wife in domestic violence is not only reflected in regulating emotions, impulse control, optimism, causal analysis, empathy, and self-efficacy but is also formed from the ability to survive and negotiate with violence. A study (Wedaningtyas \& Herdiyanto, 2017) involving a wife of a domestic violence victim as a respondent explained that resilience could come from belief values in individuals that encourage individuals to be willing to learn to adapt while living a married life.

Wagnild and Young (1993) stated that personal characteristics and an individual's ability to cope with change or adversity successfully are called resilience. According to Fraser et al. (1999) resilience is defined as an unexpected or successful adaptation to negative life events, trauma, stress, and other forms of risk. Reivich and Shatte (2002) revealed that resilience is the ability to persevere and adapt to difficult circumstances. Connor and Davidson (2003) argued that resilience is the quality of a person's ability to survive, adapt to difficult conditions, and continue life after experiencing unpleasant or stressful situations.

Resilience can be defined as the ability to recover or bounce back, as etymologically, resilience comes from the Latin words salire: "to jump", and resilire: "to jump back" (Davidson et al., 2005). Referring to WHO, Nashori and Saputro (2021) defined resilience as an adaptation process in facing difficulties, trauma, tragedy, threats, or even significant sources that can cause individual stress. The concept used in this study refers to the opinion expressed by Connor and Davidson (2003) that resilience is the quality of a person's ability to survive, adapt to difficult conditions, and be able to continue life after experiencing unpleasant things or situations with heavy pressure.

Lee et al. (2013) stated that two psychological factors are associated with resilience: risk and protective factors. Risk factors increase the likelihood of maladaptation, while protective factors are factors with characteristics that can increase adaptability. Connor and Davidson (Singh \& Yu, 2010) stated that the resilience factors are personal competence, belief in oneself, accepting change positively, self-control, and the influence of spirituality. Spirituality is one protective factor that increases individual resilience because spirituality closely relates to the community's culture and way of life (Fleming \& Ledogar, 2008).

Benson et al. (Fleming \& Ledogar, 2008) said that spirituality is an intrinsic human capacity to achieve self-transcendence that is embedded in the individual, bigger than oneself, and is sacred and motivates individuals to seek meaning, purpose, and contribution in life. Individuals who have high spirituality have a strong belief in their God. This belief creates a strong control, can interpret and accept unpleasant events more positively and believe that there is something that 
Ruidahasi \& Nashori | The Effectiveness of Istighfar Dzikr Therapy in Increasing Domestic Violence Victims' Resilience

regulates every event that occurs in the universe so that tension within the individual is reduced and mental strength is increased (Pargament et al., 1990; Tedeschi \& Calhoun, 1996; Benson \& and Proctor, 2000). Examples of spiritual activities related to resilience in the Western tradition include repenting, studying with religious leaders, joining a religious community, and surrendering (Ano \& Vasconcelles, 2005).

Muhtarom (2016) stated that spirituality could be categorized into a meaningful life, more active worship, and positive social life. The category of spirituality is influenced by two factors: the experience of the teachings of $d z i k r$ and understanding $d z i k r$. The spiritual element that will be used in this research is remembrance therapy. Dzikr means remembering, a practice associated with various ritual worship in Islam. Dzikr can be divided into two forms: understood and carried out by Muslims in general and sunnah after the five daily prayers and congregational recitation activities. Also, there is $d z i k r$ done by Muslims who are members of tarekat or sufi (Subandi, 2017).

Another understanding of $d z i k r$ is always remembering Allah, fearing and hoping only in Allah, and feeling confident that humans are under Allah's will in all matters and affairs (Ash-Shiddieqy, 2001). Dzikr helps individuals' perceptions other than fear, believing that Allah will help handle any difficulty (Najati, 2005). Several $d z i k r$ recommended by the Prophet, include Subhanallah, Alhamdulillah, Laa ilaaha illallaah, Allahu Akbar, Laa haula walaa quwwata illaa billaah, Astaghfirullah, and Inna lillahi wa inna ilaihi raji'un (Shihab, 2018).

One of the readings of remembrance is the istighfar sentence. Istighfar means asking for maghfirah (forgiveness). In Arabic, the word 'maghfirah' has the same root as 'mighfar', or protective equipment/head coverings during the war (Kharisman, 2015). Another opinion says that the istighfar sentence, 'astaghfirullah', consists of 'astaghfiru' and 'Allah'. The word 'astagfiru' is taken from the word al-ghafaru, which means the gift of forgiveness from Allah to individuals who regret and ask forgiveness for all sins. Forgiveness for all these sins makes individuals heal (Shihab, 2018). Individuals who seek forgiveness can avoid difficulties and complaints (Sa'du, 2015). Another benefit of istighfar, as stated in the verse of the Qur' an QS. Hud verse 52 means: And O my people, ask forgiveness of your Lord and then repent to Him. He will send [rain from] the sky upon you in showers and increase you in strength [added] to your strength. And do not turn away, [being] criminals." From the excerpt, istighfar can multiply a person's energy and strength physically and mentally (Kharisman, 2015).

Istighfar in this study is intended as a method of psychotherapy. Psychotherapy comes from two words: psyche, which means soul, mind, or mental, and therapy, which means healing, treatment, or care. Mujib (in Amiruddin, 2015) revealed that psychotherapy is psychiatric therapy, mental therapy, or mental therapy. Dzikr therapy is used in this study because doing a lot of istighfar will make the heart calm, peaceful, and not easily swayed by the environment. As QS AzZumar: 23, dzikr is one way to get peace in life. QS. Ar-Raad: 28 means the 
Ruidahasi \& Nashori | The Effectiveness of Istighfar Dzikr Therapy in Increasing Domestic Violence Victims' Resilience

command to increase "Those who have believed and whose hearts are assured by the remembrance of Allah. Unquestionably, by the remembrance of Allah's hearts are assured." Previous research has proven that remembrance can increase self-control (Nafisa et al., 2017), subjective well-being (Martin et al., 2018), peace of mind and soul (Kumala et al., 2017; Kumala et al., 2019), spaciousness (Nashori, 2005), and forgiveness (Nashori, 2005). In addition, remembrance can also reduce anxiety (Niko, 2018) and stress (Anggraieni \& Subandi, 2014; Safitri et al., 2017).

Therefore, if the individual's stress and anxiety decrease and have a calm heart and soul, the individual will become more resilient in dealing with difficult situations and bounce back from these difficult conditions. Khairiyah et al. (2015) involved participants with Low Back Pain (LBP) that $d z i k r$ therapy has a significant effect in increasing resilience. Koenig (2009) stated that religious beliefs and $d z i k r$ could make individuals resilient by interpreting every condition throughout life, increasing a positive view of the outside world by having hope and a sense of optimism.

Another study involving remembrance therapy to increase resilience, applied to stroke patients. The study showed that $d z i k r$ therapy could not increase resilience based on statistical analysis results. However, the qualitative analysis explained that $d z i k r$ therapy could increase resilience in stroke patients. Dzikr therapy is beneficial for participants because of the therapeutic factors in it. Besides, it makes participants feel more comfortable, calm, focused, closer to Allah SWT, and better able to control emotions (Anggraini, 2018).

Dzikr therapy will bring a person to inner peace and thus will produce a solution to escape from difficult situations (Karakaş \& Geçimli, 2017; Nugrahati et al., 2018). Allah SWT will cover sadness or bad experiences as explained by the hadith: "Whoever reproduces istighfar, Allah will surely make for every sadness a way out; and for every narrowness spaciousness; and Allah grants sustenance from unexpected directions" (Abu Daud and Nasaiy in Salim, 2006). Uyun et al. (2019) confirmed that practicing repentance and istighfar helps individuals deal with various problems such as academic problems, interpersonal relationships, and psychological problems. With istighfar, individuals can handle family and social conflicts with understanding, acceptance, and patience.

The spiritual factor increases resilience. Istighfar therapy as an intervention to increase domestic violence victims' resilience seems necessary due to the lack of research related to this issue. However, there are still studies with contradictory results related to spirituality in $d z i k r$ with resilience (Anggraini, 2018).

The purpose of this study is to determine the effectiveness of istighfar therapy in increasing domestic violence victims' resilience. This study is the first to examine the effectiveness of the istighfar therapy intervention in increasing the domestic violence victims' resilience. The researchers hypothesized a positive effect of istighfar therapy on the resilience of domestic violence victims in the treatment group. 
Ruidahasi \& Nashori | The Effectiveness of Istighfar Dzikr Therapy in Increasing Domestic Violence Victims' Resilience

\section{METHODS}

\section{Research Design}

This research used mixed methods with sequential explanatory design. A sequential explanatory design begins with collecting and analyzing quantitative data. Furthermore, the collection and analysis of qualitative data are built based on the initial results of quantitative data (Creswell, 2013; Sugiyono, 2013). The priority of the method is more on quantitative data with the role of obtaining quantitative data that is measurable and descriptive, while the qualitative method plays a role in proving, deepening, and expanding quantitative data.

The quantitative research design used was a quasi-experimental design with a nonrandomized control group pre-test post-test design. In this design, the treatment group is the group that underwent the intervention, while the control group was the group that did not receive the intervention. Both groups were given the same pre-test, post-test, and follow-up measurements (Hastjarjo, 2019). Determination of the treatment group and control group members will use the random assignment to groups technique. This technique helps control extraneous variables (Goldberg, 2019). Before the intervention, each participant had the same criteria, then divided into two groups, namely the treatment group and the control group.

Table 1. Research Design

\begin{tabular}{|c|c|c|c|}
\hline O1 & $\mathbf{X}$ & $\mathrm{O} 2$ & O5 \\
\hline O3 & - & $\mathrm{O} 4$ & O6 \\
\hline \multicolumn{4}{|c|}{ Description: } \\
\hline \multicolumn{4}{|c|}{$\mathrm{O} 1=$ Measurement of the pre-test treatment group } \\
\hline \multicolumn{4}{|c|}{$\mathrm{O} 2=$ Measurement of post-test treatment group } \\
\hline \multicolumn{4}{|c|}{$\mathrm{X}=$ Treatment } \\
\hline \multicolumn{4}{|c|}{$\mathrm{O} 3=$ Pre-test control group measurement } \\
\hline \multicolumn{4}{|c|}{ O4 = Measurement of post-test control group } \\
\hline \multicolumn{4}{|c|}{ O5 and O6 = Follow-up measurements } \\
\hline
\end{tabular}

The pre-test was carried out before treatment by giving the CD-RISC scale. The post-test was carried out right after the entire treatment activities were completed with the CD-RISC scale to determine changes in the condition of the participants before and after being given treatment. Follow-up was after two weeks of the end of the treatment activities. The CD-RISC scale used during the pre-test and posttest was returned to see the effectiveness of therapy treatment in increasing domestic violence victims' resilience.

\section{Participants}

The sampling method in this study was the purposive sampling technique. According to Etikan et al. (2016), purposive sampling is a technique for determining research samples with certain considerations to make the data obtained later on more representative. Purposive sampling is appropriate when 
Ruidahasi \& Nashori | The Effectiveness of Istighfar Dzikr Therapy in Increasing Domestic Violence Victims' Resilience

a study requires special criteria so that the samples taken later following the research objectives can solve research problems. The criteria for the participants of this study include: (1) being female, (2) having moderate and low resilience scores, (3) being Muslim, (4) being in a marital relationship and experiencing domestic violence, (5) having an age of 20-50 years.

\section{Data Collection Method}

The measurement of resilience used the Connor-Davidson Resilience Scale (CDRISC), consisting of 25 items. The CD-RISC was compiled by Connor and Davidson (2003) with a Likert scale model with a score of 0 to 4 (Disagree, Disagree, Somewhat Agree, Agree, Strongly Agree) and based on five aspects of resilience according to Connor and Davidson. The lowest score that participants may obtain is 0 , and the highest score that participants may obtain is 100 . Subjects with a score of 0-56 are in a low category, subjects with a score of 57-80 are in the medium category and subjects with a score of 81-100 are in the high category. Cronbach's alpha for the full scale was 0.89 , and the correlation between items ranged from 0.30 to 0.70 . In the research of Windle et al. (2011), CD-RISC is one of the three measuring instruments that received the highest rating in the value of validity and reliability of the 15 resilience measuring instruments tested.

Besides filling in the scale, the data of this research was conducted by interview and observation. Interviews were conducted at the follow-up stage. The interview process was only used in the follow-up process because at the stage before therapy, during therapy, and after therapy, participants were given scales and worksheets based on modules. The interviews were conducted to obtain qualitative data to strengthen the quantitative data obtained and to find out the benefits and changes felt by the participants after attending remembrance therapy.

Data was through observation during the training. Aspects observed during the training included: (1) general impression: physical condition and general appearance; (2) social relationships: relationships that participants build with other participants or with facilitators \& co-facilitators; (3) attitude/response: attitude/response during the therapy process (during experience sharing sessions, doing assignment sheets, listening to the facilitator and practicing remembrance); (4) liveliness: initiative, asking questions, courage, and enthusiasm that arise.

\section{Intervention Procedure}

The initial procedure is the preparatory stage. At this stage, the researchers conducted an initial survey to see the actual problem based on data sourced from the field. Next, the researchers made a research proposal based on the data, prepared to measure instruments, developed research methods, determined the target participants and the modules. The module in this study is a module compiled by the research team (Kartikasari et al., 2021) with a modification of the 
Kumala et al. (2019) and the Wulandari and Nashori (2014) module based on the stages of remembrance therapy by Subandi (2017). Istighfar therapy consisted of 12 sessions divided into three meetings. Each meeting took about 120 minutes, with 5-6 hours of treatment. Next is to prepare the qualifications of Facilitator and Co-Facilitator. The criteria for selecting a facilitator include: (1) a therapist/psychologist who has a Psychologist Practice License (SIPP), (2) is Muslim, (3) having experience in providing $d z i k r$ therapy, especially istighfar, (4) willing to be fully involved in the intervention process, (5) having good interpersonal skills during the intervention.

The next procedure is the implementation stage. At this stage, the first step is to give a pre-test. The purpose of giving the pre-test was to determine the initial condition of the participants' level of resilience before the therapy by giving a CD-RISC scale of 25 items. Participants were grouped into a treatment group and a control group. Furthermore, the intervention is the istighfar therapy. The intervention of istighfar remembrance therapy in this study used a previously designed module. After the intervention was completed, a post-test was given to the participants. The purpose of giving a post-test is to determine the condition of the participants' resilience level after attending istighfar remembrance therapy by giving a CD-RISC scale of 25 items. After two weeks from the intervention time, participants were given follow-up. The purpose of providing follow-up is to determine the effectiveness of istighfar therapy in increasing domestic violence victims' resilience by providing a CD-RISC scale of 25 items.

The next procedure is the reporting stage. This stage is conducted after the follow-up process. The researchers analyzed and processed pre-test, post-test and follow-up data. Next, a research report contains answers to the research hypotheses and various information obtained from these results.

\section{Data Analysis Technique}

The data analysis technique in this study used a quantitative approach to analyze the difference in scores between the treatment group and the control group and between participants in the treatment group. Quantitative data analysis used Statistical Product and Service Solution (SPSS) version 25 software. The analysis used was ANOVA Mixed Design (Chartier \& Cousineau, 2011). It is called Mixed Design because it combines two sub-analyses, namely the Within Subject Test and Between Subject Test. Within Subject Test is a test of differences in scores in one group (pre-test and post-test) and Between Subject Test is a test of difference in scores between the treatment group and the control group (Murrar \& Brauer, 2018).

\section{RESULTS}

The participants in this study were 12 women who had moderate and low resilience scores, were Muslim, were in a marital relationship and experienced domestic violence. Participants were divided into two groups (treatment and 
Ruidahasi \& Nashori | The Effectiveness of Istighfar Dzikr Therapy in Increasing Domestic Violence Victims' Resilience

control) by the random assignment method. Details of the descriptions of research participants are described in Graph 1 and Graph 2.

Graph 1. Description of Treatment Group Participants

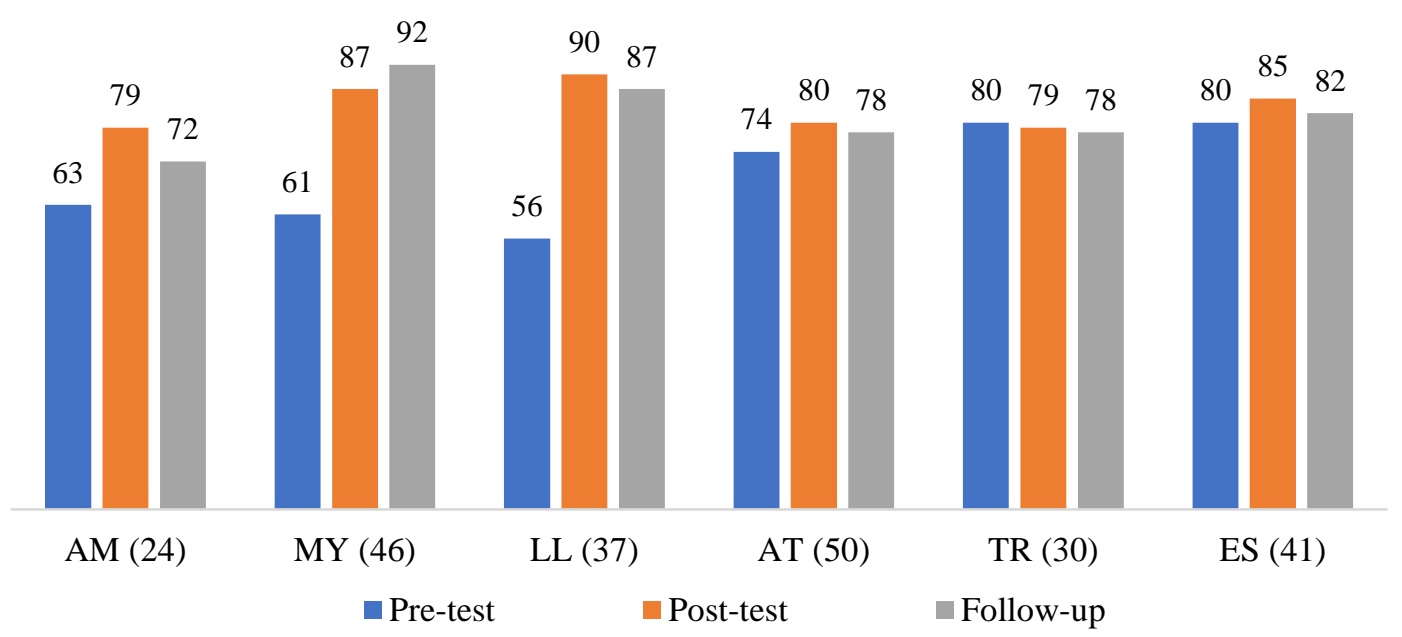

Graph 2. Description of Control Group Participants

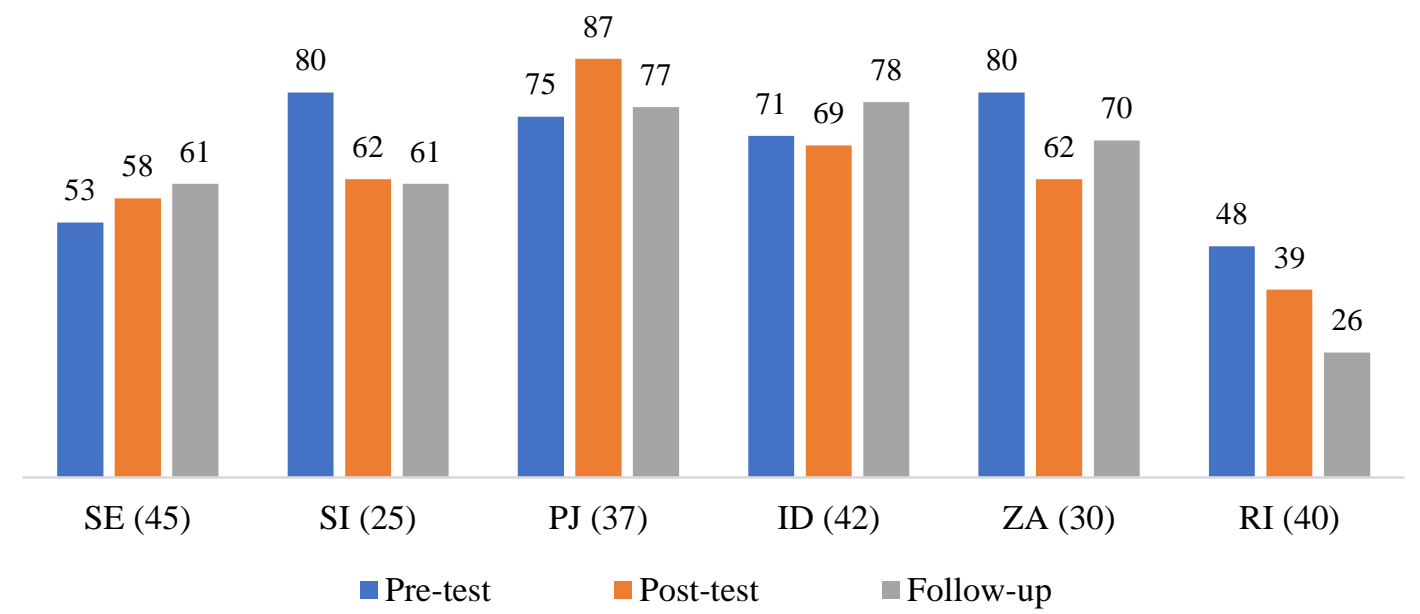

\section{Descriptive Analysis Results}

This study provides information on descriptive statistics for each group. Twelve (12) participants were divided into two groups. The treatment group consisted of 6 participants, and the control group consisted of 6 participants. The description of the data obtained from the pre-test, post-test, and follow-up results is the resilience score of the wife of the victim of domestic violence who became the research participant. The results of the descriptive analysis are described in Table 2. 
Ruidahasi \& Nashori | The Effectiveness of Istighfar Dzikr Therapy in Increasing Domestic Violence Victims' Resilience

Table 2. Description of Research Statistics

\begin{tabular}{lllll}
\hline Group & & Mean & Std. Deviation & $\mathrm{N}$ \\
\hline Pre-test & Treatment & 69.00 & 10.35 & 6 \\
& Control & 68.83 & 15.03 & 6 \\
& Total & 68.92 & 12.31 & 12 \\
\hline Post-test & Treatment & 83.33 & 4.67 & 6 \\
& Control & 62.83 & 15.58 & 6 \\
& Total & 73.08 & 15.32 & 12 \\
\hline Follow-up & Treatment & 81.50 & 7.14 & 6 \\
& Control & 62.17 & 19.19 & 6 \\
& Total & 71.83 & 17.10 & 12 \\
\hline
\end{tabular}

The average resilience score obtained by the treatment and control groups is not much different at the pre-test $(\mathrm{XKE}=69,00$ and $\mathrm{XKK}=68,83)$, with the standard deviation of the control group being greater than the treatment group (SKK= $15,03$ and $S K E=10,35)$. Furthermore, at the post-test, the average results of the resilience scores obtained by the two groups show differences. The average posttest score of resilience in the treatment group $(\overline{X K E}=83,33)$ is greater than the post-test mean in the control group $(X=62,83)$ with a standard deviation of greater than the control group (SKK $=15,58$ and $S K E=4,67)$. The mean score of the treatment group $(\overline{X K E}=81,50)$ also shows greater than the mean score of the control group $(\overline{X K k}=62,17)$ at follow-up, with the standard deviation of the control group being significantly higher than the treatment group (SKK= 19,19 and $S K E=7,14)$. The magnitude of the standard deviation value of the resilience score of the treatment group compared to the control group indicates that the resilience score in the control group is more varied than the treatment group. However, the mean score of the treatment group experienced an increase and was higher than that of the control group during post-test and follow-up.

\section{Hypothesis Test Results}

The hypothesis proposed by this study is that there is an effect of istighfar therapy on domestic violence victims' resilience in the treatment group seen from the difference in resilience scores between the treatment group and the control group at the time before, after, and follow-up within two weeks after the intervention.

Table 3. Tests of Within-Subjects Effects

\begin{tabular}{|c|c|c|c|c|c|c|c|}
\hline Source & & $\begin{array}{l}\text { Type III } \\
\text { Sum of } \\
\text { Squares }\end{array}$ & $\mathrm{df}$ & $\begin{array}{l}\text { Mean } \\
\text { Square }\end{array}$ & $\mathrm{F}$ & Sig. & $\begin{array}{l}\text { Partial Eta } \\
\text { Squared }\end{array}$ \\
\hline $\begin{array}{l}\text { time * } \\
\text { Group }\end{array}$ & $\begin{array}{l}\text { Greenhouse- } \\
\text { Geisser }\end{array}$ & 782.167 & 1.380 & 566.933 & 5.292 & .029 & .346 \\
\hline
\end{tabular}


Ruidahasi \& Nashori | The Effectiveness of Istighfar Dzikr Therapy in Increasing Domestic Violence Victims' Resilience

The significant results in Table 6 can be seen based on the time*group row in the Greenhouse-Geisser sub row (Leech et al., 2005). Table 6 shows F= 5,292 and Sig. $0.029(\mathrm{p}<0.05)$, meaning that there is an interaction between time (pre-test-posttest-follow-up) and group (treatment-control). The interaction showed that the changes in pre-test scores to follow-up in the two groups (treatment-control) differed significantly. There is an interaction score in each group, so there is a difference in the resilience scores of participants in the treatment group and participants in the control group. With these significant results, the analysis is continued with the explanation from Table 7.

Table 4. Pairwise Comparisons

\begin{tabular}{|c|c|c|c|c|c|c|c|}
\hline \multirow[t]{3}{*}{ Group } & \multirow[t]{3}{*}{ (I) time } & \multirow[t]{3}{*}{ (J) time } & \multirow{3}{*}{$\begin{array}{l}\text { Mean } \\
\text { Diff.erence } \\
(\mathrm{I}-\mathrm{J})\end{array}$} & \multirow[t]{3}{*}{$\begin{array}{l}\text { Std. } \\
\text { Error }\end{array}$} & \multirow[t]{3}{*}{ Sig.b } & \multicolumn{2}{|c|}{$\begin{array}{l}\text { 95\% Confidence Interval } \\
\text { for Difference }\end{array}$} \\
\hline & & & & & & Lower & Upper \\
\hline & & & & & & Bound & Bound \\
\hline \multirow[t]{4}{*}{ Treatment } & \multirow[t]{2}{*}{ Pre-test } & Post-test & $-14.333^{*}$ & 5.537 & .027 & -26.670 & -1.997 \\
\hline & & $\begin{array}{l}\text { Follow- } \\
\text { up }\end{array}$ & -12.500 & 5.912 & .061 & -25.672 & .672 \\
\hline & \multirow{2}{*}{$\begin{array}{l}\text { Post- } \\
\text { test }\end{array}$} & Pre-test & $14.333^{*}$ & 5.537 & .027 & 1.997 & 26.670 \\
\hline & & $\begin{array}{l}\text { Follow- } \\
\text { up }\end{array}$ & 1.833 & 2.881 & .539 & -4.587 & 8.254 \\
\hline \multirow[t]{4}{*}{ Control } & \multirow[t]{2}{*}{ Pre-test } & Post-test & 6.000 & 5.537 & .304 & -6.337 & 18.337 \\
\hline & & $\begin{array}{l}\text { Follow- } \\
\text { up }\end{array}$ & 6.667 & 5.912 & .286 & -6.505 & 19.839 \\
\hline & \multirow{2}{*}{$\begin{array}{l}\text { Post- } \\
\text { test }\end{array}$} & Pre-test & -6.000 & 5.537 & .304 & -18.337 & 6.337 \\
\hline & & $\begin{array}{l}\text { Follow- } \\
\text { up }\end{array}$ & .667 & 2.881 & .822 & -5.754 & 7.087 \\
\hline
\end{tabular}

Table 4 shows that in the treatment group, resilience scores from pre-test to posttest $(M D=-14.33)$ are significant $(p<0.05)$. Furthermore, the decrease in resilience scores from post-test to follow-up $(M D=1.83)$ is not significant $(p>0.05)$. Meanwhile, the decrease in the control group from pre-test to post-test $(\mathrm{MD}=6.00)$ is not significant $(\mathrm{p}>0.05)$. Then, the decrease in resilience scores from post-test to follow-up $(\mathrm{MD}=0.66)$ is not significant $(\mathrm{p}>0.05)$. Therefore, the hypothesis is accepted, with a difference in resilience scores between the treatment and control groups.

Istighfar therapy helped the domestic violence victim's resilience in the treatment group.

Table 5. Multivariate Tests

\begin{tabular}{llllllll}
\hline Group & & Value & F & $\begin{array}{l}\text { Hypoth } \\
\text { esis df }\end{array}$ & $\begin{array}{l}\text { Error } \\
\text { df }\end{array}$ & Sig. & $\begin{array}{l}\text { Partial Eta } \\
\text { Squared }\end{array}$ \\
\hline Treatment & Wilks' lambda & .595 & $3.060 \mathrm{a}$ & 2.000 & 9.000 & .097 & .405 \\
\hline
\end{tabular}


Ruidahasi \& Nashori | The Effectiveness of Istighfar Dzikr Therapy in Increasing Domestic Violence Victims' Resilience

The effective contribution can be seen in Table 5 in the Wilks' Lambda column, referring to the opinion of Leech et al. (2005). Partial Eta Squared in the experimental group is 0.405 , showing that istighfar therapy increases resilience by $40.5 \%$.

\section{Qualitative Analysis Results}

The qualitative analysis came from observations during the istighfar therapy and interviews after the therapy. Qualitative data collection was carried out on the treatment group participants. Based on the qualitative analysis, the participants generally said that the most memorable part of the therapy was the psychoeducation process. Participants had new knowledge and understanding related to istighfar. Thus, participants could better interpret istighfar sentence. After interpreting while reading istighfar, participants became more able to calm down, focus, accept and find a way out of the difficult conditions. Besides, group therapy is beneficial for the participants. Participants could share, empathize, and strengthen each other. Participants felt more empowered after undergoing therapy because they had a better relationship with Allah through istighfar and had support from other participants.

\section{DISCUSSION}

This study aims to determine the effectiveness of istighfar therapy in increasing domestic violence victims' resilience. Based on the quantitative data analysis, there were differences in the resilience level in the treatment group before and after being given istighfar therapy. This result answers the hypothesis that there is a significant change in the resilience score of the victims after being in the therapy compared to the control group participants.

The findings of this study are in line with Khairiyah et al. (2015), explaining that $d z i k r$ could increase individual resilience in dealing with problems and increase mental strength. Therefore, a spiritual approach with istighfar therapy can help individuals become more resilient. Another study conducted by Sulfahmi and Ridha (2017) showed that the quality of the tahajjud prayer, which is an extension of the meaning of $d z i k r$, had a positive relationship with the level of individual resilience.

The results are also in line with several previous studies showing the effectiveness of psychological interventions based on the Islamic spiritual approach in improving mental health and overcoming psychological problems (Kumala et al., 2017; Leguminosa et al., 2017; Jayanti et al., 2019; Nafisa et al., 2017; Safitri et al., 2017; Putra \& Nashori, 2021; Purnomo et al., 2021). This study also strengthens the previous findings compiled by Nashori et al. (2019) that Islamic psychology interventions can be classified as original and integrative Islamic psychology interventions. Original Islamic psychology is purely based on Islamic teachings. Meanwhile, integrative Islamic psychology integrates perspectives from psychological thought and research. Both Islamic 
Ruidahasi \& Nashori | The Effectiveness of Istighfar Dzikr Therapy in Increasing Domestic Violence Victims' Resilience

psychological interventions have been proven to play a role in improving individual psychological conditions (Nashori et al., 2019). Therefore, a spiritual approach can help individuals to improve their mental health.

Istighfar is explained as medicine for soul-healing the soul to ask for forgiveness from Allah. Istighfar is also interpreted as regret for the sins committed. Thus, the belief in forgiveness for these sins makes the soul heal in the individual (Shihab, 2018). This research is also in line with Uyun et al. (2019), explaining that repentance and istighfar help individuals find solutions to various problems and deal with these problems with understanding, acceptance, and patience. Spirituality can increase individual resilience (Hunter-Hernández et al., 2016), and daily Islamic routines such as istighfar which is incorporated in therapy, can facilitate the healing process of mental health (Hasanović et al., 2017).

The quantitative data analysis in this study was strengthened by the qualitative analysis showing that all participants in the treatment group felt the difference in conditions and positive benefits after participating in istighfar therapy. Participants felt some benefits such as a sense of calm, patience, acceptance, and ability to deal with difficult situations. Khairiyah et al. (2015) explained that repeated remembrance would bring peace, security, and comfort and increase the ability to adapt more positively.

Before istighfar therapy was given, participants had many worries related to problems in domestic life. The participants had negative thought patterns accompanied by anxiety due to a lack of peace and tranquility in their hearts (Fadilah \& Madjid, 2020). As known, lack of peace and tranquility will affect the level of individual resilience (Fredrickson et al., 2003). So, in this study, participants were helped to face problems by asking forgiveness from Allah, reading istighfar and interpreting the feeling of returning and surrendering to Allah.

After undergoing istighfar therapy, participants realized that worry and anxiety were due to a distant relationship with Allah SWT. Awareness of the mistakes or sins committed and the distance from the relationship with Allah raises the belief that every problem experienced will be passed because Allah always provides help to His servants, and Allah always forgives His repentant servants (Koenig, 2009; Shihab, 2018). Participants become more resilient and confident that they can change for the better in the future by improving their relationship with God. The process of istighfar therapy in groups also supported an increase in the participants' resilience. In the groups, participants could interact with other participants. Stories of experiences and feedback from other participants become support. Thus, there is a sense of togetherness, openness in conveying emotions, sympathy and empathy that can bring happiness and strength to participants (Mey et al., 2021).

This study also has limitations related to internal validity. Internal validity is the degree to which the observed results represent the truth in the population and, as such, are not due to methodological errors (Patino \& Ferreira, 2018). Flannelly 
et al. (2018) explained that seven internal validity threats could affect conclusions in experimental research. Flannelly et al. (2018) stated that what commonly occurs in quasi-experiments is the threat of experience, maturation, testing, statistical regression, subject selection and mortality. The closest threat to internal validity in this research is history. Historical threats are the participants' experiences or events during the experiment that are not part of the given intervention, referred to as extraneous variables. This threat is avoidable with a short implementation time or hospitalization (Flannelly et al., 2018). However, it cannot be applied in this study.

Another limitation is the timeliness of the participants. Some participants were late in the meeting, affecting the participants' focus and understanding of the presented material. Then, the istighfar therapy to control participants' remembrance activity is also a limitation in this study because the application can only be accessed using a mobile phone, while participants are not always in a condition to be able to hold a mobile phone when they want to do istighfar or $d z i k r$.

This study has a weakness: some participants in the treatment group did not follow predetermined criteria because of the difficulty finding participants who fit the criteria and were willing to follow the process while being research participants. Systematic differences such as characteristics in research (Hastjarjo, 2016) in marital status threaten internal validity.

\section{CONCLUSIONS}

The results showed a significant difference in resilience scores between the wives as domestic violence victims in the treatment group after being given the intervention of istighfar therapy compared to the control group participants. Thus, istighfar therapy was effective in increasing the victims' resilience. The results of a qualitative analysis also revealed a change in each participant's psychological condition after the therapy.

Based on the evaluation, there are several suggestions for further research. Further research is expected to conduct tighter control regarding the selection of subjects to fit the predetermined criteria. Further research also should arrange a more effective time to avoid threats from foreign variables.

Future researchers are expected to make more effective and efficient techniques for recording the participants' remembrance. The participants in the study need to be increased to strengthen the findings and represent the population. Then, the researchers suggest participants commit to the istighfar therapy. According to the minimum recommended amount, the expected commitment is to do $d z i k r 100$ times daily. This treatment will allow the participants to interpret better and be resilient. Participants are also expected to disseminate their knowledge to istighfar therapy to the social environment. 
Ruidahasi \& Nashori | The Effectiveness of Istighfar Dzikr Therapy in Increasing Domestic Violence Victims' Resilience

\section{REFERENCES}

Aditya, P. (2014). Kecenderungan bunuh diri pada istri korban KDRT di Kabupaten Semarang [Undergraduate thesis, Universitas Sultan Agung]. Indonesia.

Amiruddin, B. (2015). Psikoterapi dalam perspektif Islam. Ihya al 'Arabiyah, 5(1), 60-67.

Anggraieni, W. N. \& Subandi, S. (2014). Pengaruh terapi dzikir untuk menurunkan stress pada penderita hipertensi esensial. Jurnal Intervensi Psikologi, 6(1), 81-102. https:// doi.org/10.20885/intervensipsikologi.vol6.iss1.art6

Anggraini, A. (2018). Pengaruh terapi dzikir terhadap peningkatan resiliensi pada pasien stroke. (Publication no. 9504) [Undergraduate thesis, Universitas Islam Indonesia]. Universitas Islam Indonesia e-Repository.

Annisa, R. (2018). Data kekerasan terhadap perempuan dan anak tahun 2012-2017. https://rifka-annisa.org/id/layanan/data-kasus

Ano, G. G., \& Vasconcelles, E. B. (2005). Religious coping and psychological adjustment to stress: A meta-analysis. Journal of Clinical Psychology, 61(4), 461-480. https://doi.org/10.1002/jclp.20049

Ash-Shiddieqy, H., T., M. (2001). Falsafah hukum Islam. Pustaka Rizki Putra.

Basri, S., Kasim, S., \& Roslan, S. (2018). Kekerasan dalam rumah tangga (KDRT) yang dialami suami. Neo Societal, 3(2), 457-466.

Benson H \& Proctor W. (2000). Keimanan yang menyembuhkan dasar-dasar respon relaksasi. Kaifa.

Chartier, S. \& Cousineau, D. (2011). Computing mixed-design (split-plot) ANOVA. The Mathematica Journal, 13,1-22. https:/ / doi.org/10.3888/tmj.13$\underline{17}$

Connor, K. M., \& Davidson, J. R. T. (2003). Development of a new resilience scale: The Connor-Davidson Resilience scale (CD-RISC). Depression and Anxiety, 18(2), 76-82. https:// doi.org/10.1002/ da.10113

Creswell, J., W. (2013). Research design: Pendekatan kualitatif, kuantitatif, dan mixed. Pustaka Pelajar.

Dala, S., A., U. (2019). Resiliensi pada istri korban kekerasan dalam rumah tangga. (Publication no. 4935) [Undergraduate thesis, Universitas Mercu Buana 
Ruidahasi \& Nashori | The Effectiveness of Istighfar Dzikr Therapy in Increasing Domestic Violence Victims' Resilience

Yogyakarta]. Universitas Mercu Buana Yogyakarta e-Repository.

Davidson, J. R. T., Payne, V. M., Connor, K. M., Foa, E. B., Rothbaum, B. O., Hertzberg, M. A., \& Weisler, R. H. (2005). Trauma, resilience and saliostasis: Effects of treatment in post-traumatic stress disorder. International Clinical Psychopharmacology, 20(1), 43-48. https://doi.org/10.1097/00004850200501000-00009

Deborah, S., Muthmainnah, A., \& Herlinda, L. S. T. (2018). Trauma dan resiliensi pada wanita penyitas kekerasan dalam rumah tangga. Jurnal Ilmiah Psikologi MANASA, 7(2), 121-130.

Efendi, R. (2020, 25 Febuari). Kesal sering dimarahi, istri aniaya suami di deli serdang. Liputan6.com. https:// www.liputan6.com/regional/read/4186494/kesalsering-dimarahi-istri-aniaya-suami-di-deli-serdang

Enam, L. (2018, 27 November). Kisah-kisah perlawanan perempuan korban kekerasan suami. Liputan6.com. https://kaltimkece.id/warta/terkini/picu-bunuhdiri-tren-kdrt-kaltim-meresahkan

Erniati. (2015). Kekerasan dalam rumah tangga. Musawa, 7(2), 207-233.

Etikan, I. (2016). Comparison of convenience sampling and purposive sampling. American Journal of Theoretical and Applied Statistics, 5(1), 1. https://doi.org/10.11648/j.ajtas.20160501.11

Fadilah, R., \& Madjid, A. (2020). Patience therapy to reduce adolescents' anxiety assessed from personality and parenting. International Journal of Islamic Educational Psychology, 1(1), 1-11. http://dx.doi.org/10.18196/ijiep.1101

Flannelly, K. J., Flannelly, L. T., \& Jankowski, K. R. B. (2018). Threats to the internal validity of experimental and quasi-experimental research in healthcare. Journal of Health Care Chaplaincy, 24(3), 107-130. https://doi.org/10.1080/08854726.2017.1421019

Fleming, J., \& Ledogar, R. J. (2008). Resilience and indigenous spirituality: A Literature Review. Pimatisiwin, 6(2), 47-64.

Fraser, M. W., Richman, J. M., \& Galinsky, M. J. (1999). Risk, protection, and resilience: Toward a conceptual framework for social work practice. Social Work Research. https:/ / doi.org/10.1093/swr/23.3.131

Fredrickson, B. L., Tugade, M. M., Waugh, C. E., \& Larkin, G. R. (2003). What good are positive emotions in crisis?. Journal of Personality and Social Psychology, 84(2), 365-376. 
Ruidahasi \& Nashori | The Effectiveness of Istighfar Dzikr Therapy in Increasing Domestic Violence Victims' Resilience

Goldberg, M. H. (2019). How often does random assignment fail? Estimates and recommendations. Journal of Environmental Psychology, 66, Article 101351. https:// doi.org/10.1016/i.jenvp.2019.101351

Hasanović, M. (2017). Spiritual and religious Islamic perspectives of healing of post-traumatic stress disorder. Insights on the Depression and Anxiety, 1(1), 23-29. https:// doi.org/10.29328/journal.hda.1001004

Hastjarjo, T. D. (2016). Validitas eksperimen. Buletin Psikologi, 19(2), 70-80. https://doi.org/10.22146/bpsi.11558

Hastjarjo, T. D. (2019). Rancangan eksperimen-kuasi. Buletin Psikologi, 27(2), 187. https:// doi.org/10.22146/ buletinpsikologi.38619

Hunter-Hernández, M., Costas-Muñíz, R., \& Gany, F. (2015). Missed opportunity: Spirituality as a bridge to resilience in latinos with cancer. Journal of religion and health, 54(6), 2367-2375. https://doi.org/10.1007/s10943-015-0020-y

Ikrawati, I., Roslan, S., \& Sarpin, S. (2016). Tindakan kekerasan terhadap anak dalam rumah tangga di Desa Lelamo Kecamatan Kulisusu Utara Kabupaten Buton Utara. Jurnal Neo Societal, 70-80.

Jayanti, A., Nashori, F., \& Rumiani, R. (2019). Terapi ruqyah syar'iyyah meningkatkan kebahagiaan perempuan korban kekerasan dalam rumah tangga. Jurnal Intervensi Psikologi (JIP), 11(2), 111-122. https:/ / doi.org/10.20885/intervensipsikologi.vol11.iss2.art5

JPNN.com. (2020, 24 Januari). Jadi korban kdrt, istri balas dendam bunuh suami yang tidur pulas. JPNN.com. https://www.jpnn.com/news/jadi-korban-kdrtistri-balas-dendam-bunuh-suami-yang-tidur-pulas

Karakaş, A. C., \& Geçimli, G. (2017). The effect of istighfar on state and trait anxiety. International Journal of Psychology and Educational Studies, 4(3), 73-79. https:// doi.org/10.17220/ijpes.2017.03.008

Kartikasari, M. N. D., Parwatiningsih, S. A., \& Fatsena, R. A. (2021). Evaluasi metode continuity of care pada tugas akhir mahasiswa prodi DIII kebidanan. Jurnal Keperawatan Jiwa (JKJ): Persatuan Perawat Nasional Indonesia, 9(1), 197-204. https:/ / doi.org/10.26714/jkj.9.1.2021.197-204

Kementerian Pemberdayaan Perempuan dan Perlindungan Anak. (2011). Kekerasan terhadap perempuan: Kekerasan dalam rumah tangga dan perdagangan orang. $\quad$ https://kemenpppa.go.id/lib/uploads/list/7970a-5a3f9-8.-kekerasanterhadap-perempuan.pdf 
Ruidahasi \& Nashori | The Effectiveness of Istighfar Dzikr Therapy in Increasing Domestic Violence Victims' Resilience

Khairiyah, U., Prabandari, Y. S., \& Uyun, Q. (2016). Terapi zikir terhadap peningkatan resiliensi penderita low back pain (LBP). Jurnal Ilmiah Psikologi Terapan, 3(2), 359-369. https://doi.org/10.22219/jipt.v3i2.3537

Kharisman, A., U., (2015). Sukses dunia akhirat dengan istighfar dan taubat. Pustaka Hudaya.

Koenig, H. G. (2009). Research on religion, spirituality, and mental health: A review. Canadian Journal of Psychiatry, 54(5), 283-291. https:// doi.org/10.1177/070674370905400502

Komisi Nasional Anti Kekerasan terhadap Perempuan. (2016). Kekerasan terhadap perempuan meluas: Negara urgen hadir hentikan kekerasan terhadap perempuan di ranah domestik, komunitas dan negara. In Catatan Tahunan (CATAHU) Tentang Kekerasan Terhadap Perempuan Tahun 2015. https://komnasperempuan.go.id/catatan-tahunan-detail/catahu-2016kekerasan-terhadap-perempuan-meluas-negara-urgen-hadir-hentikankekerasan-terhadap-perempuan-di-ranah-domestik-komunitas-dannegara-catatan-kekerasan-terhadap-perempuan-tahun-2015.

Komisi Nasional Anti Kekerasan terhadap Perempuan. (2017). Labirin kekerasan terhadap perempuan: dari gang rape hingga femicide, alarm bagi negara untuk bertindak tepat. In Lembar Fakta Catatan Tahunan (CATAHU) Komnas Perempuan tahun 2017. https://komnasperempuan.go.id/catatan-tahunandetail/lembar-fakta-catatan-tahunan-catahu-komnas-perempuan-tahun2017-labirin-kekerasan-terhadap-perempuan-dari-gang-rape-hinggafemicide-alarm-bagi-negara-untuk-bertindak-tepat

Komisi Nasional Anti Kekerasan terhadap Perempuan. (2018). Tergerusnya ruang aman perempuan dalam pusaran politik populisme. catatan kekerasan terhadap perempuan tahun 2017. In Lembar Fakta dan Poin Kunci Catatan Tahunan (CATAHU) Komnas Perempuan Tahun 2018. https://komnasperempuan.go.id/catatan-tahunan-detail/catahu-2018tergerusnya-ruang-aman-perempuan-dalam-pusaran-politik-populismecatatan-kekerasan-terhadap-perempuan-tahun-2017

Komisi Nasional Anti Kekerasan terhadap Perempuan. (2019). Korban bersuara, data berbicara, sahkan RUU penghapusan kekerasan seksual sebagai wujud komitmen negara. Catatan kekerasan terhadap perempuan tahun 2018. in Catatan tahunan (CATAHU) tentang kekerasan terhadap perempuan tahun 2018. https://komnasperempuan.go.id/catatan-tahunandetail/catahu-2019-korban-bersuara-data-berbicara-sahkan-ruupenghapusan-kekerasan-seksual-sebagai-wujud-komitmen-negaracatatan-kekerasan-terhadap-perempuan-tahun-2018 
Ruidahasi \& Nashori | The Effectiveness of Istighfar Dzikr Therapy in Increasing Domestic Violence Victims' Resilience

Komisi Nasional Anti Kekerasan terhadap Perempuan. (2020). Kekerasan terhadap perempuan meningkat: Kebijakan penghapusan kekerasan seksual menciptakan ruang aman bagi perempuan dan anak perempuan. Catatan kekerasan terhadap perempuan tahun 2019. In Catatan tahunan (CATAHU) tentang kekerasan terhadap perempuan tahun 2019. https://komnasperempuan.go.id/catatan-tahunan-detail/catahu-2020kekerasan-terhadap-perempuan-meningkat-kebijakan-penghapusankekerasan-seksual-menciptakan-ruang-aman-bagi-perempuan-dan-anakperempuan-catatan-kekerasan-terhadap-perempuan-tahun-2019

Kumala, O. D., Kusprayogi, Y., \& Nashori, F. (2017). Efektivitas pelatihan dzikir dalam meningkatkan ketenangan jiwa pada lansia penderita hipertensi. Psympathic: Jurnal Ilmiah Psikologi, 4(1), 55-66. https:// doi.org/10.15575/psy.v4i1.1260

Kumala, O. D., Rusdi, A., \& Rumiani, R. (2019). Terapi dzikir untuk meningkatkan ketenangan hati pada pengguna napza. Jurnal Intervensi Psikologi (JIP), 11(1), https:// doi.org/10.20885/intervensipsikologi.vol11.iss1.art4

Lee, J. H., Nam, S. K., Kim, A. R., Kim, B., Lee, M. Y., \& Lee, S. M. (2013). Resilience: A meta-analytic approach. Journal of Counseling and Development, 91, 269-279. https:// doi.org/10.1002/j.1556-6676.2013.00095.x

Leech, N. L., Barrett, K. C., \& Morgan, G. A. (2005). SPSS for intermediate statistics: Use and interpretation. Lawrence Erlbaum Associates, Publishers Mahwah.

Leguminosa, P., Nashori, F., \& Rachmawati, M. A. (2017). Pelatihan kebersyukuran untuk menurunkan stres kerja guru di sekolah inklusi. $\begin{array}{llll}\text { Jurnal Ilmiah Psikologi Terapan, } & 186 .\end{array}$ https://doi.org/10.22219/jipt.v5i2.4563

Liputan6.com. (2019, 22 Agustus). Kasus kekerasan anak kepada ibu di surabaya diselesaikan dengan kekeluargaan. Liputan6.com, Surabaya. https:/ / surabaya.liputan6.com/read/4044295/kasus-kekerasan-anakkepada-ibu-di-surabaya-selesai-dengan-kekeluargaan

Maisah, M., \& SS, Y. (2016). Dampak psikologis korban kekerasan dalam rumah tangga di Kota Jambi. ESENSIA: Jurnal Ilmu-Ilmu Ushuluddin, 7(2), 265-277. https://doi.org/10.14421/esensia.v17i2.1292

Martin, I., Nuryoto, S., \& Urbayatun, S. (2018). Relaksasi dzikir untuk meningkatkan kesejahteraan subjektif remaja santri. Psikis: Jurnal Psikologi 
Ruidahasi \& Nashori | The Effectiveness of Istighfar Dzikr Therapy in Increasing Domestic Violence Victims' Resilience

Islami, 4(2), 112-123. https:// doi.org/10.19109/psikis.v4i2.1965

Mei, S. T. L., Ni, A. O. Z., Sivaguru, S. A., \& Cong, C. W. (2021). Social support, resilience, and happiness in response to COVID-19. Journal of Cognitive Sciences and Human Development, 7(1), 134-144. https://doi.org/10.33736/jcshd.2882.2021

Muhajarah, K. (2017). Kekerasan terhadap perempuan dalam rumah tangga: Perspektif sosio-budaya, hukum, dan agama. Sawwa: Jurnal Studi Gender, 11(2), 127-145. https:// doi.org/10.21580/sa.v11i2.1452

Muhtarom, A. (2016). Peningkatan spiritualitas melalui zikir berjamaah (studi terhadap jamaah zikir kazus sholawat Kota Pekalongan, Jawa Tengah). Anil Islam: Jurnal Kebudayaan dan Ilmu Keislaman, 9(2), 248-267.

Muliawan, F. (2018, 29 November). Picu bunuh diri, tren KDRT Kaltim meresahkan. Kaltimkece.id. https://kaltimkece.id/warta/terkini/picu-bunuh-diritren-kdrt-kaltim-meresahkan

Murrar, S., \& Brauer, M. (2018). Mixed model analysis of variance. In B. Frey (Ed.), The SAGE encyclopedia of educational research, measurement, and evaluation (Vol. 1, pp. 1075-1078). SAGE Publications, Inc., https://www.doi.org/10.4135/9781506326139.n436

Mustaqim, A. (2020, 20 Januari). 329 Kasus kekerasan perempuan terjadi di diy pada 2019.

Medcom.id.

https://www.medcom.id/nasional/daerah/zNP41M7N-329-kasuskekerasan-perempuan-terjadi-di-diy-pada-2019

Nafisa, I. N. K., Nashori, F., \& Rumiani, R. (2017). Effectiveness of asmaul husna $d z i k r$ therapy to enhance the self-control of alcohol abuser. Jurnal Kedokteran dan Kesehatan Indonesia, 8(3), 154-163. https://doi.org/10.20885/jkki.vol8.iss3.art3

Najati, M. U. (2005). Psikologi dalam Al-Qur'an: Terapi Qur'ani dalam penyembuhan gangguan kejiwaan, terj. M. Zaka Al-Farisi. Bandung: Pustaka Setia.

Nashori, F. \& Saputro, I. (2021). Psikologi resiliensi. Universitas Islam Indonesia.

Nashori, F. (2005). Hubungan antara kualitas dan intensitas dzikir dengan kelapangdadaan mahasiswa. Millah: Jurnal Studi Agama, 51(1), 121-135. https://doi.org/10.20885/millah.vol5.iss1.art9

Nashori, F. (2005). Hubungan kualitas zikir dan pemaafan pada mahasiswa. Jurnal Psikologi, 9(1), 27-35. 
Ruidahasi \& Nashori | The Effectiveness of Istighfar Dzikr Therapy in Increasing Domestic Violence Victims' Resilience

Nashori, H. F., Diana, R. R., \& Hidayat, B. (2019). "Chapter 9 the trends in islamic psychology in Indonesia". In Research in the Social Scientific Study of Religion, Volume $30 . \quad$ Leiden, The Netherlands: Brill. https:// doi.org/10.1163/9789004416987_010

Nasution, S., M. (2019, 2 September). Kasus istri bunuh suami terungkap. Antaranews.com. https://www.antaranews.com/berita/1040708/kasusistri-bunuh-suami-terungkap

Niko, P. (2018). Pengaruh terapi dzikir untuk menurunkan kecemasan pada ibu hamil. Jurnal Islamika, 1(1), 24-33.

Nugrahati, D., Uyun, Q., \& Nugraha, S. (2018). Pengaruh terapi taubat dan istighfar dalam menurunkan kecemasan mahasiswa. JIP (Jurnal Intervensi Psikologi), 10(1), https:// doi.org/10.20885/intervensipsikologi.vol10.iss1.art3

33-41.

Pargament, K. I., Ensing, D. S., Falgout, K., Olsen, H., \& Reilly, B., Van Haitsma, K. \& Warren, R. (1990). God help me: (I): Religious coping efforts as predictors of the outcomes to significant negative life events. American Journal of Community Psychology. 18(6), 793-824. https:// doi.org/10.1007/BF00938065

Patino, C. M., \& Ferreira, J. C. (2018). Internal and external validity: can you apply research study results to your patients?. Jornal brasileiro de pneumologia : publicacao oficial da Sociedade Brasileira de Pneumologia e Tisilogia, 44(3), 183. https:// doi.org/10.1590/S1806-37562018000000164

Purnomo, N. A. S., Nashori, F., \& Astuti, Y. D. (2021). Efektivitas terapi kebermaknaan hidup dalam meningkatkan resiliensi pada odapus. Jurnal Ilmiah Psikomuda Connectedness, 9(1), 28-43.

Putra, M. F. E., \& Nashori, F. (2021). The effectiveness of reflective-intuitive alfatihah reading therapy reducing autoimmune survivor stress. Jurnal Fuaduna: Kajian Keagamaan dan Kemasyarakatan, 5(1), 83-94. http://dx.doi.org/10.30983/fuaduna.v5i1.4218

Ramadani, M., \& Yuliani, F. (2017). Kekerasan dalam rumah tangga (KDRT) sebagai salah satu isu kesehatan masyarakat secara global. Jurnal Kesehatan Masyarakat Andalas, 9(2), 80-87. https:// doi.org/10.24893/jkma.v9i2.191

Redaksi. (2020, 21 Februari). Breaking news: Istri bunuh suami di Agam. Langgam.id. https://langgam.id/breaking-news-istri-bunuh-suami-diagam/ 
Ruidahasi \& Nashori | The Effectiveness of Istighfar Dzikr Therapy in Increasing Domestic Violence Victims' Resilience

Reivich, K., \& Shatté, A. (2002). The resilience factor: 7 essential skills for overcoming life's inevitable obstacles. Broadway Books.

Rosadi, S. (2018, 5 Desember). Marah dinasehati karena bangun siang, abg aniaya ayah hingga babak belur. Merdeka.com. https:// www.merdeka.com/peristiwa/marah-dinasihati-karena-bangunsiang-abg-aniaya-ayah-hingga-babak-belur.html

Sa'du, A. A. (2015). Jangan remehkan amalan-amalan ringan. Yogyakarta: Sabil.

Safitri, S., Nashori, F., \& Sulistyarini, I. (2017). Efektivitas relaksasi zikir untuk menurunkan tingkat stres pada remaja diabetes melitus tipe II. JIP (Jurnal $\begin{array}{lll}\text { Intervensi Psikologi), } & \text { 9(1), }\end{array}$ https://doi.org/10.20885/intervensipsikologi.vo19.iss1.art1

Salim, I. M. (2006). Doa pembersih dosa: Keajaiban istigfar. PT Mizan Publika.

Sari, J., S. (2018). Hubungan antara pemaafan dan resiliensi pada perempuan yang mengalami kekerasan dalam rumah tangga. [Undergraduate thesis, Universitas Islam Indonesia]. Universitas Islam Indonesia e-Repository. https:// dspace.uii.ac.id/handle/123456789/7951

Shihab, M. Q. (2018). Wawasan Al-Quran tentang doa dan zikir. PT Lentera Hati.

Singh, K., \& Yu, X. (2010). Psychometric evaluation of the connor-davidson resilience scale (CD-RISC) in a sample of Indian students. Journal of Psychology, 1(1), 23-30. https://doi.org/10.1080/09764224.2010.11885442

Subandi. (2017). Psikologi dzikir: Studi fenomenologi pengalaman transformasi religius. Jurnal Ilmiah Indonesia.

Sugiyono. (2013). Metode penelitian kuantitatif, kualitatif, dan kombinasi (mixed methods). Alfabeta.

Sulfahmi, A., \& Ridha, A. A. (2017). Resiliensi remaja yatim piatu yang melaksanakan shalat tahajud. Psikologika: Jurnal Pemikiran dan Penelitian Psikologi, 22(2), 36-47. https:// doi.org/10.20885/psikologika.vol22.iss2.art4

Sutrisminah, E. (2012). Dampak kekerasan pada istri dalam rumah tangga terhadap kesehatan reproduksi. Majalah Ilmiah Sultan Agung, 20(127).

Tedeschi, R. G., \& Calhoun, L. G. (1996). The posttraumatic growth inventory: Measuring the positive legacy of trauma. Journal of Traumatic Stress, 9(3), 
Ruidahasi \& Nashori | The Effectiveness of Istighfar Dzikr Therapy in Increasing Domestic Violence Victims' Resilience

\section{5-472. https://doi.org/10.1002/jts.2490090305}

Uyun, Q., Kurniawan, I. N., \& Jaufalaily, N. (2019). Repentance and seeking forgiveness: the effects of spiritual therapy based on Islamic tenets to improve mental health. Mental Health, Religion and Culture, 22(2), 185-194. https://doi.org/10.1080/13674676.2018.1514593

Vinatalia, R., Marchira, C., \& Winarso, M. (2009). Hubungan kekerasan dalam rumah tangga dengan depresi pada wanita yang melakukan konsultasi di Rifka Annisa women's crisis center Yogyakarta. Jurnal Ilmu Keperawatan, $4(1), 12-16$.

Wagnild, G. M., \& Young, H. M. (1993). Development and psychometric evaluation of the resilience scale. Journal of Nursing Measurement, 1(2), 165178.

Wedaningtyas, P. A. M. P. P., \& Herdiyanto, Y. K. (2017). Tuah keto dadi nak luh Bali: Memahami resiliensi pada perempuan yang mengalami KDRT dan tinggal di pedesaan. Jurnal Psikologi Udayana, 4(1), 9-19. https:// doi.org/10.24843/jpu.2017.v04.i01.p02

Windle, G., Bennett, K. M., \& Noyes, J. (2011). A methodological review of resilience measurement scales. Health and Quality of Life Outcomes, 9(8), 1-18. https:// doi.org/10.1186/1477-7525-9-8

World Health Organization. (2020). COVID-19 and violence against women: What the health sector/system can do. WHO/SRH/20.04. https://apps.who.int/iris/bitstream/handle/10665/331699/WHO-SRH20.04-eng.pdf?ua $=1$

Wulandari, E., \& Nashori, F. (2014). Pengaruh terapi zikir terhadap kesejahteraan psikologis pada lansia. JIP (Jurnal Intervensi Psikologi), 6(2), 235-250. 